Please cite this article as:

Chiaroni D, Chiesa V, Franzò S, Frattini F, Manfredi Latilla V (2017).

The Impact of the Electricity Tariff Reform on Renewable Energies and Energy Efficiency Investments: the Case of the Italian Residential Market

International Journal of Green Energy, vol. 14 (11), pp. 889-898.

(DOI: https://doi.org/10.1080/15435075.2017.1336715) 


\title{
The Impact of the Electricity Tariff Reform on Renewable Energies and Energy Efficiency Investments: the Case of the Italian Residential Market
}

Davide Chiaroni $^{\mathrm{a}}$, Vittorio Chiesa ${ }^{\mathrm{a}}$, Simone Franzò ${ }^{\mathrm{a}}$, Federico Frattini ${ }^{\mathrm{a}}$, Vito Manfredi Latilla $^{\mathrm{a}}$

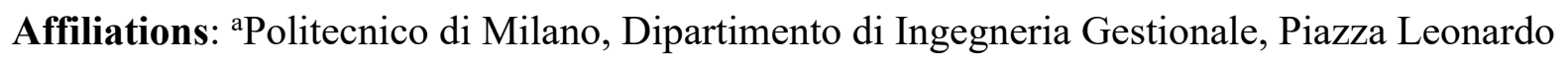
da Vinci 32, 20133 Milano, Italy

\begin{abstract}
This paper investigates the impact that the electricity tariff reform is likely to have on investments in renewable energies (i.e., photovoltaics) and the adoption of energy efficiency measures (i.e., installation of heat pumps and efficient home appliances) in the residential market in Italy. The study develops detailed cost comparisons and simulations considering two different investment scenarios (before and after the reform) to conclude that the reform will: (i) have a negative impact on investments in photovoltaic systems; (ii) favour the adoption of energy efficiency measures, such as efficient home appliances.
\end{abstract}


Keywords: Renewable Energy, Energy Efficiency, Energy Policy, Photovoltaic, Heat Pump, Home Appliances, Electricity Tariff 


\section{Introduction}

The electricity sector is going through a transformation driven by technological changes and, most importantly, national and supranational policies aimed at tackling three major challenges, i.e., environmental sustainability, energy supply security, and sustainable economic development (European Commission, 2007). Technological advancements have led to significant cost and performance improvements for some renewable energy sources (RES), such as onshore wind and photovoltaics (PV) (Hirth, 2013). The combination of technological advances, innovative financing, deal structuring, and business model configurations, have led to the increasing cost competitiveness of RES (Stark, Pless, Logan, Zhou, and Arent, 2015). Furthermore, recent policies foresee more stringent targets in terms of $\mathrm{CO}_{2}$ emission, increased penetration of RES, and higher levels of energy efficiency (Manzano-Agugliaro, Alcayde, Montoya, Zapata-Sierra, and Gil, 2013), thereby bestowing a strategic role to electricity and heat generation from RES and to the adoption of energy efficiency measures (EEM) (Viola et al., 2014; Pantaleo, Camporeale, and Shah, 2013).

At the European level, the European Commission's strategy to deal with climate change (European Commission, 2015) focuses on the need to reduce emissions by $40 \%$ and increase the electricity produced from RES to $27 \%$ by 2030 (COM(2012) 663 final, 2012; $\operatorname{COM}(2012)$ 271, 2012; European Directive 28, 2009). RES generated electricity accounts for $27.5 \%$ of EU28 gross electricity consumption (Eurostat, 2016). In terms of total investments in new RES plants in Europe, wind power accounts for 38\%, photovoltaics for around $36 \%$ and hydroelectric power plants for around 14\% (Figure 1) (Energy\&Strategy, 2016a).

The high penetration of RES in the electricity generation mix significantly affects the price dynamics and network congestion, and as a result, the performance of the electricity market (Cucchiella, D'Adamo, and Gastaldi, 2012). This is particularly relevant in the Italian market, one of the most developed in Europe in terms of renewable energy penetration, and plays a 
major role in terms of EEM investments (ACEEE, 2016; ENEA, 2015). In Italy, new investments in PV systems in 2015 totalled $€ 558$ million, equal to $290 \mathrm{MW}$ of new installed capacity. Investments in the residential market segment (including systems with a power rate of up to $20 \mathrm{~kW}$ ) accounted for $51 \%$ of total investments, equal to $55 \%$ of total new power installed capacity (Figure 2) (Energy\&Strategy, 2016a). Overall, 23,788 MW of RES plants were installed in Italy between 2010-2015 (Table 1). In the first quarter of 2016, new installed PV systems amounted to $195 \mathrm{MW}$, up 46\% compared with the same period in 2015. Nevertheless, in the first quarter of 2016, the aggregate value of new PV, wind and hydroelectric installations was 19\% less than the installed capacity in the same quarter in 2015 (ANIE, 2016). Moreover, in the first nine months of 2016, the RES energy produced covered $30.8 \%$ of total energy demand in Italy, down $3.8 \%$ compared with the same period in 2015 and 4.2\% compared to the same period in 2014 (TERNA, 2016; Gestore Servizi Energetici, 2016).

Energy efficiency in conjunction with RES constitutes another pillar of the European strategy to reduce carbon emissions, since EEM can contribute significantly to the reduction of energy consumption (Gestlberger, Dachs, Knudsen, and Schroter, 2016; Chiaroni, Chiesa, Franzo', Frattini, and Manfredi Latilla, 2016; Blok et al., 2015; Ponsa, Bikfalvia, Llacha, and Palcicb, 2013). In recent years, energy efficiency has become part of national and international policy discussions and is recognized as a relevant factor of sustainable environmental and economic growth (Karimu and Brännlund, 2015; Geller, Harrington, Levine, Rosenfeld, and Tanishima, 2006). Specifically, implementing EEM is of paramount importance at the EU level where electricity prices tend to be higher compared to other geographic areas (Astrov, HanzlWeiss, Leitner, Pindyuk, Poschl, and Stehrer, 2015). Hence, the EU has established a set of binding measures to help EU countries reach the $20 \%$ energy efficiency target by 2020 , requiring member states to use energy more efficiently at all stages of the energy chain, from production to final consumption (European Directive 27, 2012). In the last four years, EEM 
investments showed a Compound Annual Growth Rate (CAGR) of over 10\% at the European level (Energy\&Strategy, 2015b). In this regard, Italy has adopted a national energy strategy that prioritizes energy efficiency as the cornerstone of energy supply security, reducing energy costs for citizens and businesses, and ensuring environmental protection through greenhouse gas reductions (Ministero dello Sviluppo Economico, 2013). Thanks to proactive legislation, Italy is ranked second worldwide among the most energy-efficient countries (ACEEE, 2016), and investments in EEM continue to increase, up to over $€ 7.9$ billion in 2015 (Energy\&Strategy, 2015b). The residential sector in 2015 was responsible for the majority of total EEM investments, followed by the industrial sector (ENEA, 2016). Specifically, energyefficient home appliances (with a market value of more than 2 billion $€$ ) constituted the most adopted EEM in the residential sector in 2015, followed by heat pumps, which accounted for more than 1 billion $€$ (Figure 3) (Energy\&Strategy, 2016b).

In this scenario, the electricity tariff reform for the residential market in Italy (hereinafter, "reform") entered into force on 1 January 2016 following Deliberation 582/2015/R/EEL of the Italian Regulatory Authority for Electricity, Gas and Water (AEEGSI) (AEEGSI, 2015a), in line with the national implementation of the EU Energy Efficiency Directive (European Directive 27, 2012). The goal of the reform is to increase the electrification of residential energy consumption to fully exploit the use of electricity generated from RES, moving beyond the progressive structure of the network services and system charges tariffs introduced after the oil price shock of 1973 to discourage high electricity consumption among residential customers.

The reform is expected to have an impact on RES and EEM investments (Chiaroni et al., 2016), since the new tariff structure of electricity bills will affect the profitability of such investments. Electricity generation is a sector where investments are determined by several factors, such as public policies, country generation mix, wholesale energy prices, availability 
of resources, administrative procedures, and social acceptance of new technology systems (Bechberger and Reiche, 2004). Furthermore, economic policies (such as investment subsidies) and regulatory policies (such as the enforcement of new tariffs) play a key role in defining the electricity market regulatory framework, affecting the amount of money that will flow to new RES projects and develop further EEM (Mignon and Bergek, 2016). This is particularly relevant in the electricity generation sector where the still-comparatively higher cost of electricity produced from RES, its dispatchability and impact on the grid structure have made it virtually impossible for RES to grow without the support of regulatory intervention (Das, Bhattacharya, and Cañizares, 2014; Longo, Roscia, Lazaroiu, and Pagano, 2014; Menanteau, Dominique, and Lamy, 2003; Painuly, 2001).

\subsection{Aims and structure of the paper}

Although the role of regulatory policies in the electricity market has been widely investigated with a particular focus on their effects on the diffusion of distributed generation and the deployment of new RES investments (Del Río and Linares, 2014; Kalkuhl, Edenhofer, and Lessmanna, 2013; Battle, Pérez-Arriaga, and Zambrano-Barragán, 2012; Jäger-Waldau, Szabó, Scarlat, and Monforti-Ferrario, 2011; Badcock and Lenzen, 2010; Cossent, Gómez, and Frías, 2009), the relationship between changes in electricity tariffs and investments in RES and EEM is still under-researched in academic literature.

This paper attempts to analyse how changes in the electricity tariff for the residential market in Italy may directly affect the rate of new investments in RES and EEM. In recent years, several European countries besides Italy (i.e., Spain, Portugal, Greece, and Germany) have reformed their electricity tariff systems to adjust the fixed part of the tariff components to meet the corresponding costs borne by energy companies, since such costs are increasing due to the high penetration of RES in the energy mix (European Commission, 2014). In particular, Spain, 
Portugal, and Greece have invested massively in PV systems in the last decade, while Germany has invested in both PV systems and wind farms. The analysis, research and practical implications presented in this paper are therefore particularly timely. For researchers, this is a first attempt to fill a gap in academic literature on the analysis of the extent to which electricity tariff reforms affect RES and EEM investments. For practitioners and policy makers, this study offers some useful insights to help align ratemaking practices with the growing demand for energy production from RES and EEM at the residential level.

To achieve the objectives, the paper develops and comments on detailed cost comparisons and simulations by considering two different RES and EEM investment scenarios (i.e., before and after the reform in Italy) and modelling different consumption patterns.

Regarding RES, the paper focuses on PV systems, since these have received the largest share of investments in recent years (Figure 2), and the Italian market is now characterized by the absence of incentives and other supporting mechanisms for photovoltaic installations. Therefore, changes in the market dynamics, as introduced by the reform, may negatively affect the profitability of the PV industry (Chiaroni et al., 2014). Regarding EEM, the paper focuses on heat pumps and efficient home appliances, since these technologies are attracting a large part of EEM investments at the residential level (Figure 3). (Energy\&Strategy, 2016b).

The paper is structured as follows: Section 2 illustrates the most relevant characteristics of the reform; Section 3 describes the empirical approach and the data analysis, and paves the way for the discussion on the impact of the reform on RES and EEM investments presented in Section 4. Lastly, Section 5 offers the main conclusions of the study.

\section{The electricity tariff reform for the residential market in Italy}

The reform affects two of the four electricity bill cost components: the network services tariff and system charges tariff. The other two cost components are unaffected by the reform, 
i.e., selling service (the cost of electricity delivered to the customer) and taxes on the electric bill (including 10\% VAT and other minor fiscal duties, such as excise tax).

Network services represent the tariff for metering, marketing, and distributing electricity, and mainly reflect the cost incurred to cover network transport and the system service. As the RES penetration level increases, this cost becomes relevant, since the effect of nondispatchable energy sources on network operations is bound to increase. The system charges tariff reflects the costs of covering general services to maintain and operate the electricity system. In 2015, the most relevant components of the system charges tariff were: (i) RES incentives equal to $82.02 \%$ of the total system charges tariff; (ii) fiscal burden of financing the decommissioning of Italian nuclear plants equal to $7.03 \%$ of the total system charges tariff; (iii) actions to promote the adoption of energy efficiency measures equal to $4.13 \%$ of the total system charges tariff.

According to the tariff system in place before the reform entered into force, $99 \%$ of the electricity price related to variable components, with a progressive structure of the network and the system charges tariffs, i.e., with a kWh unit cost that increased for bands with greater offtake and thus discouraging higher levels of electricity consumption. The pre-reform system had four consumption bands: (i) below 1,800 kWh/year; (ii) between 1,800 and 2,640 kWh/year; (iii) between 2,640 and 4,400 kWh/year; (iv) over 4,440 kWh/year. Two different tariffs applied to each of these bands: (i) tariff "D2" for resident customers with a rated power of 3kW; (ii) tariff "D3" for either non-resident customers or for resident customers with a rated power above $3 \mathrm{kWh}^{*}$ (Figure 4). In 2015, the network services and system charges tariffs accounted respectively for $17.39 \%$ and $25.28 \%$ of the total average electricity price (Figure 5).

The reform introduces two major changes:

\footnotetext{
* For clarity, according to Italian legislation, the residential electricity market is constituted of resident and nonresident customers. The former reside permanently in the apartment/house, the latter use the apartment/house typically for weekends, vacations, and/or short-term periods (generally, second homes), and different tariffs apply, as will be explained in the remainder of the paper.
} 
- Regarding the network services tariff, the previous variable and progressive structure of the tariff with a $\mathrm{kWh}$ unit cost that increased for bands with greater off-take $(€ / \mathrm{kWh})$ has been replaced by a non-progressive tariff structure as detailed below:

- $\quad$ Fixed amount (€/year) for metering and marketing costs

- $\quad$ Power amount ( $€ / \mathrm{kW} / \mathrm{year})$ for the distribution cost, which becomes a fixed amount, although it depends on the installed rate-power

- Energy amount $(\mathrm{c} € / \mathrm{kWh})$ for transmission costs, which is now the only variable cost.

- Regarding the system charges tariff, the reform has completely replaced the progressive structure. $75 \%$ of the electricity bill now depends on the $\mathrm{kWh}$ used, with a tariff expressed in $\mathrm{c} € / \mathrm{kWh}$. The remaining $25 \%$ is a fixed component related to the distribution cost. A differentiation is still made between resident customers (to whom an energy amount is applied, i.e., in c€ per kWh used) and non-resident customers (to whom the tariff is applied in both the fixed amount and energy amount).

The gradual replacement of the progressive structure of the network services and system charges tariffs will be implemented in three phases over a three-year period (1 January 2016; 1 January 2017; 1 January 2018). This will generate a more linear relationship between electricity consumption $(\mathrm{kWh})$ and price paid by costumers $(€)$ (Figure 6) (Energy\&Strategy, 2016a).

Since 1 January 2016, network service tariffs are subject to a first intervention aimed at "mitigating" the progressive effect of consumption $(\mathrm{c} € / \mathrm{kWh})$ and increasing the fixed quotas. Table 2 reports the $\Delta$ price of $\mathrm{kWh}$ (referring to the two cost components affected by the reform, i.e., the network services and system charges tariffs) segmented by consumption bands. To be noted is that, following the reform, the higher the $\mathrm{kWh}$ consumption, the higher the saving compared to the previous scenario. 
From 1 January 2017, with the full application of the non-progressive tariff for network services for resident customers, only two consumption bands remain. Finally, from 1 January 2018, the reform will be fully in force, applying the non-progressive structure also to the general system cost tariff.

\section{Methodology}

This section illustrates the methodological approach followed to evaluate the effects of the reform on new RES and EEM investments. First, the effects on the electricity bill of both resident and non-resident customers are estimated, focusing on three different consumption bands, i.e., customers with a yearly consumption of $1,800 \mathrm{kWh}, 2,700 \mathrm{kWh}$, and 4,000 kWh. These represent the annual consumption of three different customer clusters in Italy (respectively, a single person, a couple with two children, and a larger family) and are the same bands that AEEGSI uses in its simulations to test the impact of new policies on end customers (AEEGSI, 2015b; AEEGSI, 2015c).

Regarding the analysis of the effects of the reform on the economic viability of RES and EEM investments, simulations were run on the same consumption bands. The financial indicators adopted to analyse the economic viability of RES and EEM investments are Net Present Value (NPV), Pay-Back Time (PBT) and Internal Rate of Return (IRR).

The NPV uses the discounted differential cash flows generated by the investment during its operation (set at 20 years in the present analysis), applying a discount rate that measures the risk level of the investment (Tudisca et al., 2013). In other words, the NPV compares the present values of the forecasted net cash inflow with the initial capex investment to determine the profitability of the investment or project (Samba Sowe, Thanarak, and Suriwong, 2014).

The NPV is calculated as follows: 


$$
N P V=\sum_{t=0}^{T} \frac{C F_{t}}{(1+i)^{t}}
$$

where:

$\mathrm{T}=$ project duration in years

$\mathrm{i}=$ discount rate, set at $4 \%$ in this analysis

$\mathrm{CF}($ Cash Flow $)=$ expected net benefit at the end of each year.

The Pay-Back Time (PBT) of an investment is a measure of the time required to reach the point at which the sum of the differential cash inflows (discounted or non-discounted) is equal to the sum of the differential cash outflows (again, discounted or non-discounted). Both cash inflows and outflows are the same as those mentioned above for the NPV calculation. Differently from the NPV, the PBT is more subjective in its application, as the decision-maker must define a maximum acceptable time (cut-off time) to define the economic feasibility of an investment. In the Italian residential sector, a typical acceptable payback threshold is approximately 6 years (Energy\&Strategy, 2015a).

The PBT is calculated as follows:

$$
\sum_{t=1}^{P B T} C F(t) /(1+\mathrm{i})^{\wedge} \mathrm{t}=0
$$

where:

PBT $=$ Pay-Back Time

$\mathrm{i}=$ discount rate

$\mathrm{CF}($ Cash Flow $)=$ expected net benefit at the end of each year (i.e., differential cash inflows minus the differential cash outflows). 
Finally, the Internal Rate of Return (IRR) is a measure of the average profitability of an investment (i.e., the discount rate that adjusts future cash flows so that they are equal to the investment outlay). Both cash inflows and outflows are the same as those for the NPV calculation. The IRR is a relative indicator, therefore a subjective threshold has to be defined for the investment's economic evaluation (Tudisca et al., 2013), such as the cost of capital.

The IRR is calculated as follows:

$$
\sum_{t=0}^{T} \frac{C F t}{(1+I R R)^{t}}=0
$$

Tables 3 and 4 show the assumptions at the base of the different simulations to evaluate the impact of the reform on RES investments, i.e., a rooftop PV system. Each customer referred to in Table 3 adopts a $3 \mathrm{~kW}$ rooftop PV system, with the characteristics detailed in Table 4, and shows a 30\% natural self-consumption rate (Chiaroni et al., 2014). Two residential customer types are analysed (resident and non-resident) and the profitability of investments is estimated in a pre-reform and post-reform scenario, i.e., with the new tariff scheme.

To empirically test the impact of the reform on the adoption of EEM, a first simulation is run on a customer who intends to replace old home appliances (i.e., a fridge, washing machine and dishwasher) in energy efficiency class A with new and more efficient appliances in energy efficiency class $\mathrm{A}++$, as summarized in Table 8.

Second, a simulation is run on the replacement of a low-efficient heat pump with a new more efficient one. Table 10 shows the technical specifications of the two heat pumps (old/new), together with the savings obtained by both a resident and non-resident customer through the adoption of a new heat pump, before and after the reform. Since the adoption of a heat pump determines a significant increase in electricity consumption, in this simulation, the electricity prices considered (c€/kWh) are those applied to the highest consumption band (i.e., 4,000 kWh/year) as referred to in Table 3 for customer \#3. 
The technical and economic data on RES and EEM were collected through a review of product data sheets, corroborated by direct interviews with a sample of manufacturers operating in the Italian market.

\section{The impact of the reform on the profitability of RES and EEM investments}

The analysis of the effects of the reform on electricity bills shows that customers with a lower annual consumption are penalized by the reform, while customers with a higher annual consumption benefit from the reform. In particular, a resident customer using 1,800 kWh/year incurs a cost of $108 € /$ year more than before, which represents a $36 \%$ increase in the electricity bill. A resident customer using 4,000 kWh/year saves $164 €$, which represents a $19.5 \%$ decrease in the electricity bill. Lastly, the reform does not have a relevant impact on customers using 2,700 kWh/year. Figure 7 shows the results of the simulations for a resident customer, while Figure 8 shows the results for a non-resident customer.

Regarding the impact of the reform on RES investments, Table 5 shows the result of the simulation for both a resident and a non-resident customer, with a yearly consumption of 1,800 $\mathrm{kWh}$, installing a rooftop PV system with the characteristics detailed in Table 4. For a resident customer, the increase in the electricity tariff is counterbalanced by a lower value for net metering (so-called "scambio sul posto"), which leads to a PBT of 16 years, 2 years longer than previously, an IRR above $6 \%$, and a NPV equal to $€ 1,543$. Comparing such values with those before the reform entered into force shows that the reform penalizes the investment in a rooftop PV system for a resident customer. For a non-resident customer, the scenario is even worse, since this customer has difficulty in self-consuming the electricity produced by the PV system due to the typical use of secondary homes for vacations or weekends. The increase in the electricity tariff is therefore not set-off by any real opportunity to self-consume the electricity produced by the rooftop PV system. 
Table 6 shows the results of the simulation for both a resident and a non-resident customer with a yearly consumption of $2,700 \mathrm{kWh}$ and installing a rooftop PV system. This scenario is particularly interesting because a yearly consumption of $2,700 \mathrm{kWh}$ represents a real case for a resident family with two children who paid $€ 521$ before the reform and is expected to pay $€ 523.8$ after the reform, thus a negligible difference (Figure 7). However, the IRR associated with this investment decreases from $7.9 \%$ to $5.8 \%$ after the reform. Such reduction is due to the worsening of net metering, since the amount reimbursed as a variable cost for services and network charges is now lower than before the reform. The IRR and NPV show similar results, bringing to light the remarkable negative effect that the reform has on an investment in a rooftop PV system for this type of customer. The same consideration can be made for a nonresident customer, with a higher PBT associated with the investment in the post-reform scenario, as well a deterioration of the other two financial indicators. The worsening of the financial indicators for this customer is somewhat mitigated by the higher electricity price this customer has to pay after the reform, equal to $25.5 \mathrm{c} € / \mathrm{kWh}$ compared to $19.4 \mathrm{c} € / \mathrm{kWh}$ for a resident customer (Table 3), making any small amount of self-consumption a valid opportunity to save on the electricity bill.

Finally, Table 7 shows the results of the simulation for both a resident and non-resident customer with a yearly consumption of $4,000 \mathrm{kWh}$. Also emerging in this case is a worsening of the IRR and other financial indicators mainly due to the decreasing structure of the electricity tariff, which incentivizes a higher level of electricity consumption, hence reducing the economic value of the energy saving generated by the self-consumption of electricity produced by a PV system. Furthermore, the non-resident customer sees a less severe worsening of the financial indicators associated with the investment in a rooftop PV system.

On the energy efficiency side, the reform provides a decisively better scenario in the case of a customer with low electricity consumption (i.e., 1,800 $\mathrm{kWh} /$ year) willing to replace less 
efficient home appliances with new efficient ones, since the PBT of such investment decreases from over 20 years to around 9 years for a resident customer compared to the pre-reform scenario, as detailed in Tables 8-9. As for the improvement of the other financial indicators, this is due to the higher electricity price $(+36 \%)$ that this customer will pay compared to before the reform.

The same investment related to the other two customer types (i.e., with an electricity consumption equal to $2,700 \mathrm{kWh} /$ year and $4,000 \mathrm{kWh} /$ year) shows a marginal improvement of the financial indicators compared to the pre-reform scenario. Also in the case of non-resident customers, the impact of the reform is positive in relation to replacing less efficient home appliances with new more efficient ones, especially for customers with low electricity consumption (i.e., $1,800 \mathrm{kWh} /$ year).

Table 11 shows the financial indicators associated with the investment in a new heat pump for a resident and a non-resident customer, before and after the reform. The PBT is almost the same in the two scenarios for both customer types, while the IRR and NPV show better values in the pre-reform scenario for both. Specifically, the non-resident customer who enjoyed better financial indicators before the reform continues to benefit from replacing an old heat pump with a new one, even though the reform worsens the actual financial benefit.

\section{Conclusions}

The goal of the reform in Italy is not to promote a general increase in energy consumption, which would be in contrast with European policies and regulations, but rather to favour the electrification of domestic consumption, incentivizing the adoption of electric appliances for residential needs. Indeed, electricity consumption is seen as a substitute for other primary energy sources that are much less renewable, making a significant contribution to environmental sustainability. Moreover, as highlighted in Section 1.1, in recent years, several 
European countries have reformed their electricity tariff systems to rebalance the domestic tariff scheme taking into account the huge contribution of distributed energy generation from RES on the overall energy mix.

Concerning Italy, the simulations show that the reform penalizes customers with low electricity consumption, while favouring customers with high energy consumption (i.e., 4,000 $\mathrm{kWh}$ ). For a customer consuming $1,800 \mathrm{kWh} /$ year, the additional cost determined by the reform is around $€ 108 /$ year ( $+36 \%$ compared to the pre-reform electricity bill), while the cost saving for a customer consuming 4,000 $\mathrm{kWh} /$ year is approximately $€ 164$ (-19.5\% on the pre-reform electricity bill). Lastly, the reform has almost no impact on customers with an electricity consumption of approximately $2,700 \mathrm{kWh} /$ year.

This gradual replacement of the progressive structure of network tariffs and general system costs with a non-progressive tariff for network services for all domestic customers represents a new and somewhat unforeseen scenario for those willing to invest in a domestic PV system, since the marginal cost of each $\mathrm{kWh}$ decreases with the increase in off-take, thus discouraging higher levels of self-consumption. The evidence from the present analysis leads to the conclusion that the reform will have a negative impact on the PV sector, with a general reduction in profitability of new investments at the residential level. In the current market scenario, exogenous factors such as the economic crisis, the trend towards a reduction in installed power, and the reduction in incentive tariffs, already undermine the growth of the PV sector in Italy.

Regarding EEM, it can be concluded that the reform introduces some opportunities for the residential market. On the one hand, reducing the progressive structure of the network services tariffs and the general system costs, the reform promotes switching to more efficient electric home appliances (in Class $\mathrm{A}++$ ), given that the associated investment provides interesting financial indicators. On the other hand, for other EEMs such as electric heat pumps, customers 
with low-efficient heat pumps will be unwilling to voluntarily replace their systems with new more efficient ones, since the expected PBT is now longer than before the reform.

The present study leaves room for further comparative studies focused on other European countries where policymakers are experiencing the same issues discussed here for Italy. Moreover, it highlights the importance for policymakers to carefully consider the impact on the diffusion of RES and EEM when designing electricity tariff reforms, since these constitute the cornerstone of achieving the targets set by energy policies at the European level.

\section{References}

ACEEE. (2016). The 2016 International Energy Efficiency Scorecard. Accessed December 10, 2016. http://aceee.org/research-report/e1602

AEEGSI. (2015a). 582/2015/R/EEL. Accessed July 20, 2016. http://www.autorita.energia.it/allegati/docs/15/582-15.pdf

AEEGSI. (2015b). Annual Report on the state of services and on regulatory activities. Roma. Accessed July 15, 2016. http://www.autorita.energia.it/allegati/relaz_ann/15/ReportBortoni_2015.pdf

AEEGSI. (2015c). Electricity reform of network tariffs in the bill to kick off from 2016 for 30 million $\begin{array}{lllll}\text { customers. } & \text { Roma. } & \text { Accessed }\end{array}$ http://www.autorita.energia.it/it/inglese/press_releases/15/151202.htm

ANIE. (2016). Osservatorio ANIE Rinnovabili primo semestre 2016. Accessed September 17, 2016. http://anie.it/osservatorio-anie-rinnovabili-primo-semestre-2016/?contesto-articolo=/salastampa/comunicati-stampa/\#.V905dpiLQ2w 
Astrov, V., D. Hanzl-Weiss, S. M. Leitner, O. Pindyuk, J. Poschl, and R. Stehrer. (2015). Energy Efficiency and EU Industrial competitiveness: Energy Costs and their Impact on Manufacturing Activity. Vien: The Vienna Institute for International Economic Studies, Research Report no. 405.

Badcock, J., and M. Lenzen. (2010). Subsidies for electricity-generating technologies: A review. Energy Policy, 38(9), 5038-5047.

Battle, C., I. Pérez-Arriaga, and P. Zambrano-Barragán. (2012). Regulatory design for RES-E support mechanisms: learning curves, market structure, and burden-sharing. Energy Policy, 41, 212 220.

Bechberger, M. and D. Reiche. (2004). Policy differences in the promotion of renewable energies in the EU member states. Energy Policy, 32(7), 843-849.

Blok, V., T. B. Long, A. I. Gaziulusoy, N. Ciliz, R. Lozano, D. Huisingh, M. Csutora, and C. Boks. (2015). From best practices to bridges for a more sustainable future: advances and challenges in the transition to global sustainable produciton and consumption. Journal of Cleaner Production(108), 19-30.

Chiaroni, D., M. Chiesa, V. Chiesa, S. Franzò, F. Frattini, and G. Toletti. (2016). Introducing a new perspective for the economic evaluation of industrial energy efficiency technologies: An empirical analysis in Italy. Sustainable Energy Technologies and Assessments, 15, 1-10.

Chiaroni, D., V. Chiesa, L. Colasanti, F. Cucchiella, I. D'Adamo, and F. Frattini. (2014). Evaluating solar energy profitability: a focus on the role of self-consumption. Energy Conversion and Management, 88, 317-331.

Chiaroni, D., V. Chiesa, S. Franzo', F. Frattini, and V. Manfredi Latilla. (2016). Overcoming Internal Barriers to Energy Efficiency through Energy Audit: a Case Study of a Large Manufacturing Company in the Home Appliances Industry. In press, 1-16.

$\operatorname{COM}(2012)$ 271. (2012). Renewable Energy: a major player in the European energy market. http://ec.europa.eu/transparency/regdoc/rep/1/2012/EN/1-2012-271-EN-F1-1.Pdf

$\operatorname{COM}(2012) 663$ final. (2012). Making the internal energy market work. https://ec.europa.eu/energy/sites/ener/files/documents/20121115_iem_0663_en.pdf

Cossent, R., T. Gómez, and P. Frías. (2009). Towards a future with large penetration of distributed generation: Is the current regulation of electricity distribution ready? Regulatory recommendations under a European perspective. Energy Policy, 37(3), 1145-1155.

Cucchiella, F., I. D'Adamo, and M. Gastaldi. (2012). Modeling optimal investments with portfolio analysis in electricity markets. Energy Educ Sci Technol Part A: Energy Sci Res, 30, 673-692.

Das, I., K. Bhattacharya, and C. Cañizares. (2014). Optimal Incentive Design for Targeted Penetration of Renewable Energy Sources. IEEE Transactions on Sustainable Energy, 5(4).

Del Río , P., and Linares, P. (2014). Back to the future? Rethinking auctions for renewable electricity support. Renewable and Sustainable Energy Reviews, 35, 42-56.

ENEA. (2015). Energy Efficiency trends and policies in Italy. ENEA. Accessed October 20, 2016. http://www.odyssee-mure.eu/publications/national-reports/energy-efficiency-italy.pdf

ENEA. (2016). Rapporto Annuale Efficienza Energetica. ENEA. Accessed October 5, 2016. http://www.enea.it/it/pubblicazioni/pdf-volumi/raee-executive-summary-2016.pdf 
Energy\&Strategy. (2015a). Intelligent Building Report. Politecnico di Milano, Dipartimento di Ingegneria Gestionale.

Energy\&Strategy. (2015b). Energy Efficiency Report. Politecnico di Milano, Dipartimento di Ingegneria Gestionale.

Energy\&Strategy. (2016a). Renewable Energy Report. Politecnico Di Milano, Dipartimento di Ingegneria Gestionale, Milano.

Energy\&Strategy. (2016b). Energy Efficiency Report. Politecnico Di Milano, Dipartimento di Ingegneria Gestionale, Milano.

European Commission. (2007). An Energy Policy for Europe. http://eur-lex.europa.eu/legalcontent/EN/TXT/?uri=URISERV\%3A127067

European Commission. (2014). Electricity Tariff Deficit: Temporary or Permanent Problem in the EU? http://ec.europa.eu/economy_finance/publications/economic_paper/2014/pdf/ecp534_en.pdf

European Commission. (2015). Investment Perspectives in the Electricity Market. http://ec.europa.eu/economy_finance/publications/eeip/pdf/ip003_en.pdf

European Directive 27. (2012). Energy Efficiency Directive. https://ec.europa.eu/energy/en/topics/energy-efficiency/energy-efficiency-directive

European Directive 28. (2009). Promotion of the use of energy from renewable sources. http://eurlex.europa.eu/legal-content/EN/TXT/PDF/?uri=CELEX:32009L0028\&from=EN

Eurostat. (2016). Renewable energy statistics. Accessed July 25, 2016. http://ec.europa.eu/eurostat/statisticsexplained/index.php/Renewable_energy_statistics\#Electricity

Geller, H., P. Harrington, M. Levine, A. Rosenfeld, and S. Tanishima. (2006). Policies for Increasing Energy Efficiency: Thirty Years of Experience in OECD. Energy policy, 34(5), 556-573.

Gestlberger, W., B. Dachs, M. Knudsen, and M. Schroter. (2016). Closing the energy-efficiency technology gap in Europea firms? Innovation and adoption of energy efficiency technologies. Journal of Engineering and Technology Management, 40, 87-100.

Gestore Servizi Energetici. (2016). Energia da Fonti Rinnovabili in Italia_Dati preliminari 2015. http://www.gse.it/it/Dati\%20e\%20Bilanci/GSE_Documenti/osservatorio\%20statistico/Stime $\% 20$ preliminari\%202015.pdf

Hirth, L. (2013). The market value of variable renewables: the effect of solar wind power variability on their relative price. Energy Economy, 38, 218-236.

Jäger-Waldau, A., M. Szabó, N. Scarlat, and F. Monforti-Ferrario. (2011). Renewable electricity in Europe. Renewable and Sustainable Energy Reviews, 15(8), 3703-3716.

Kalkuhl, M., O. Edenhofer, and K. Lessmanna. (2013). Renewable energy subsidies: Second-best policy or fatal aberration for mitigation? Resource and Energy Economics, 35(3), 217-234.

Karimu, A., and R. Brännlund. (2015). Energy efficient R\&D investment and Aggregate Energy Demand: Evidence from OECD countries. CERE Working Paper, 14, 1-29.

Longo, M., M. Roscia, G. Lazaroiu, and M. Pagano. (2014). Analysis of sustainable and competitive energy system. 3rd International Conference on Renewable Energy Research and Applications (ICRERA), 80-86. 
Manzano-Agugliaro, F., A. Alcayde, F. Montoya, A. Zapata-Sierra, and C. Gil. (2013). Scientific production of renewable energies worldwide: An overview. Renewable Sustainability Energy Review, 18, 134-143.

Menanteau, P., D. Dominique, and M. Lamy. (2003). Prices versus quantities: Choosing policies for promoting the development of renewable energy. Energy Policy, 31, 799-812.

Mignon, I., and A. Bergek. (2016). Investments in renewable electricity produciton: the importance of policy revised. Renewable Energy(86), 307-316.

Ministero Dello Sviluppo Economico. (2013). Strategia Energetica Nazionale: per un'energia più competitiva e sostenibile. http://www.sviluppoeconomico.gov.it/images/stories/normativa/20130314_Strategia_Energeti ca_Nazionale.pdf

Painuly, J. (2001). Barriers to renewable energy penetration; a framework for analysis. Renewable Energy, 24, 73-89.

Pantaleo, A., S. Camporeale, and N. Shah. (2013). Thermo-economic assessment of externally fired micro-gas turbine fired by natural gas and biomass: Applications in Italy. Energy Conversion Management, 75, 202-213.

Ponsa, M., A. Bikfalvia, J. Llacha, and I. Palcicb. (2013). Exploring the impact of energy efficiency technologies on manufacturing firm performance. Journal of Cleaner Production, 52, 134-144.

Samba Sowe, K., P. Thanarak, and T. Suriwong. (2014). Technical and Economic Viability Assessment of PV Power Plants for Rural Electrification in the Gambia. Energy Procedia, 52, 389-398.

Stark, C., J. Pless, J. Logan, E. Zhou, and D. Arent. (2015). Renewable Electricity: Insights from the coming decade. Joint Institute for Strategic Energy Analysis, Denver(USA). Accessed October 21, 2016. http://www.nrel.gov/docs/fy15osti/63604.pdf

TERNA. (2016). Rapporto Mensile sul Sistema Elettrico. TERNA. Accessed October 25, 2016. http://www.qualenergia.it/sites/default/files/articolo-doc/RapportoTerna_settembre_2016_0.pdf

Tudisca, S., A. Di Trapani, F. Sgroi, R. Testa, and R. Squatrito. (2013). Economic analysis of PV systems on buildings in Sicilian farms. Renewable and Sustainable Energy Review, 28, 691701.

Viola, F., P. Romano, R. Miceli, D. La Cascia, M. Longo, and G. Sauba. (2014). Economical evaluation of ecological benefits of the demand side management,. 3rd International Conference on Renewable Energy Research and Applications (ICRERA), 995-1000. 


\section{FIGURES AND TABLES}

Figure 1. Share of investments in new RES plants at the EU level in 2015 (Energy\&Strategy, 2016a)

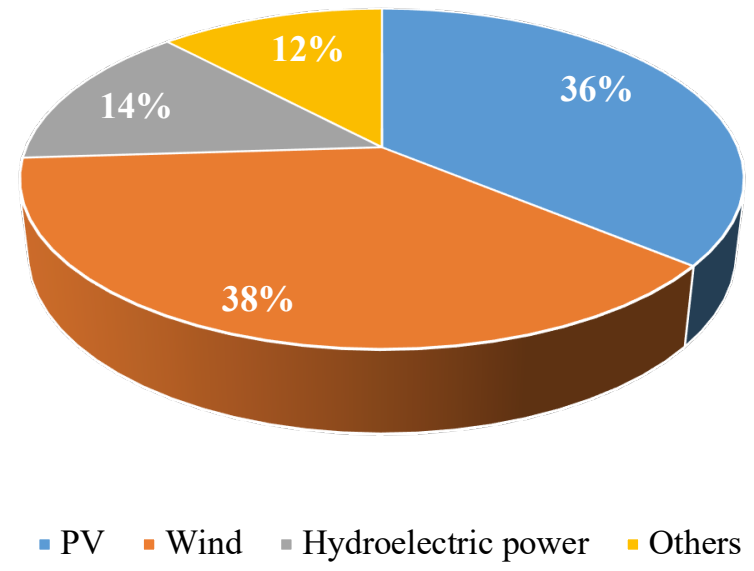

Figure 2. Cumulative RES installed capacity in Italy over the period 2008-2015 (Energy\&Strategy, 2016a)

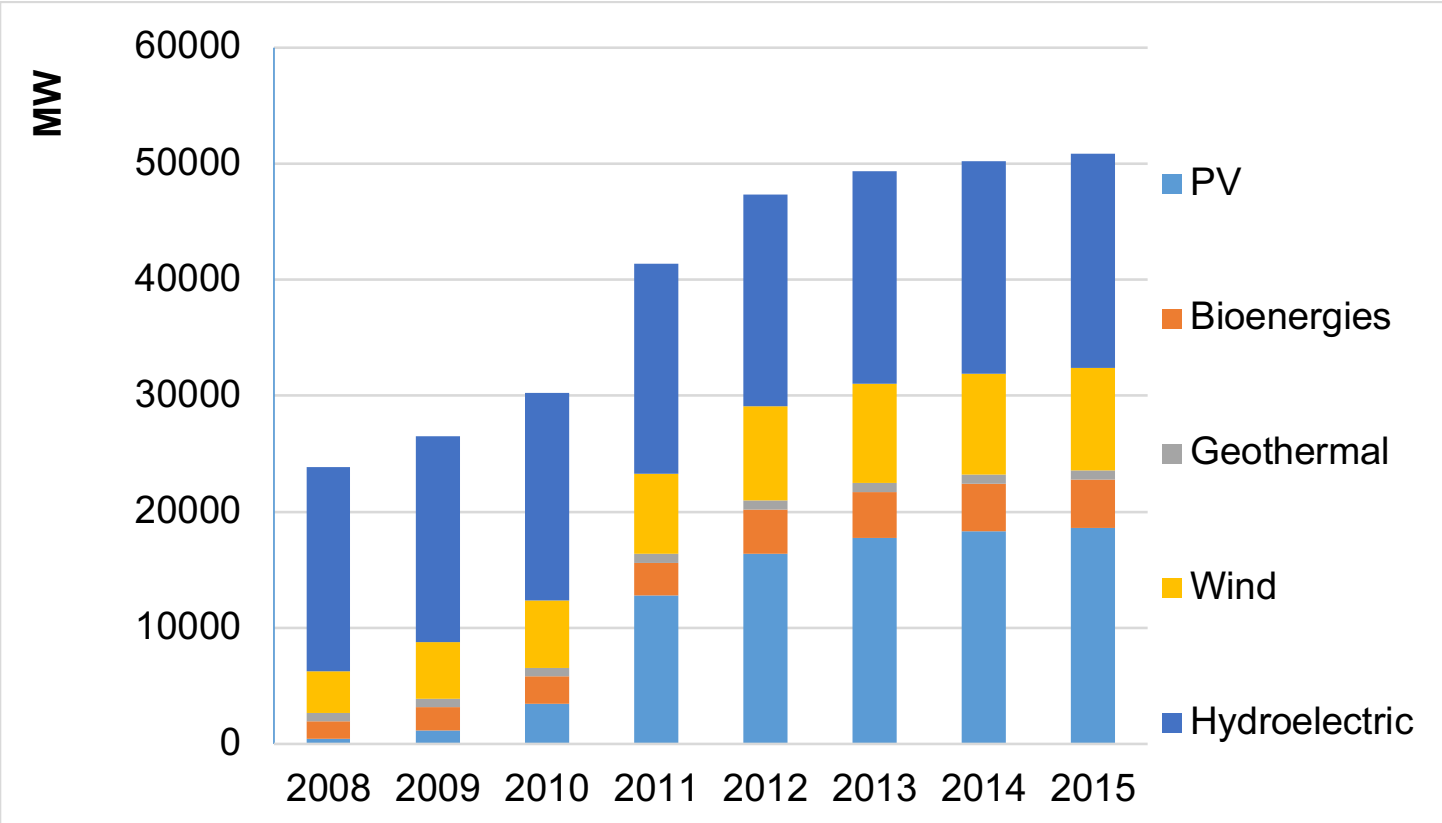


Figure 3. Investment breakdown in EEM for the residential sector in Italy in 2015 (million $€$ ) (Energy\&Strategy, 2016b)

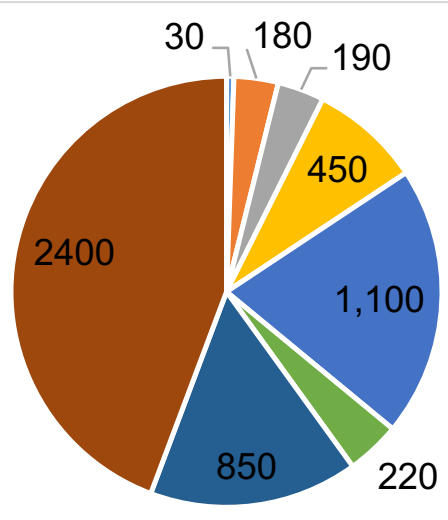

- Building automation

- Combined Heat \& Power

- Insulated glazing

- Lighting

- Heat Pumps

- Solar thermal plants

- Building insulation

- Home appliances (big)

Figure 4. Electricity tariff breakdown (variable part) before the reform for a resident and non-resident customer (Energy\&Strategy, 2016a)

Tarifff D2 variable part [€/KWh]

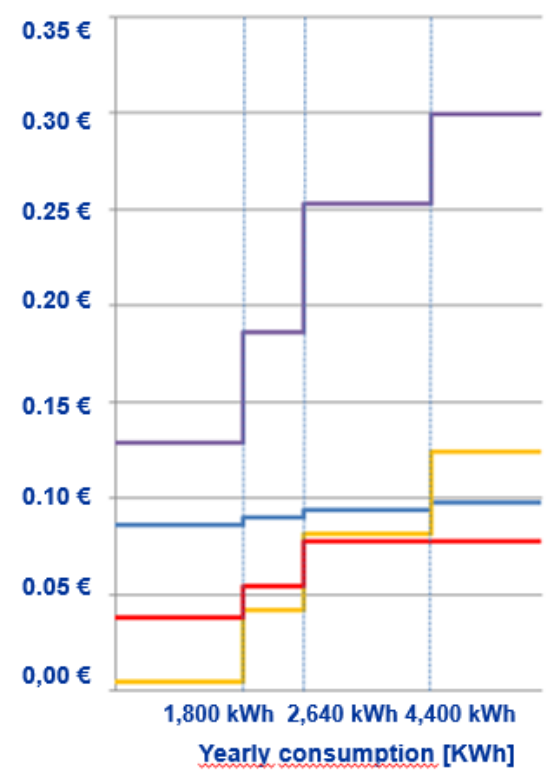

Tariff D3 variable part [€/KWh]

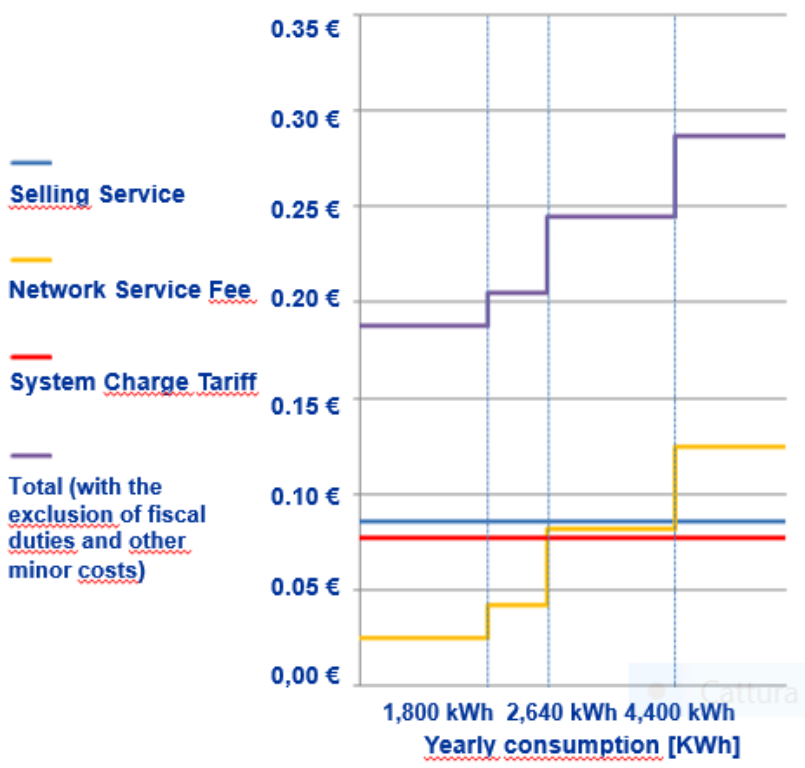


Figure 5. Electricity tariff breakdown in 2015 (Energy\&Strategy, 2016a)

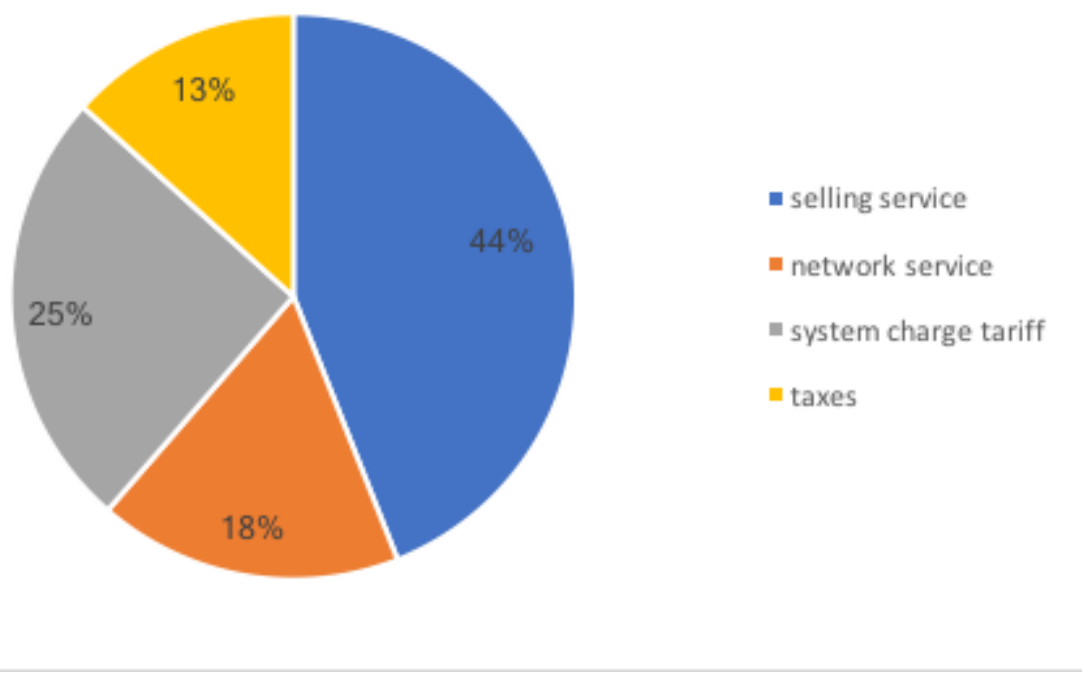

Figure 6 Yearly changes in electricity bills before and after the reform for a resident (D2) and non-resident (D3) customer (Energy\&Strategy, 2016a)

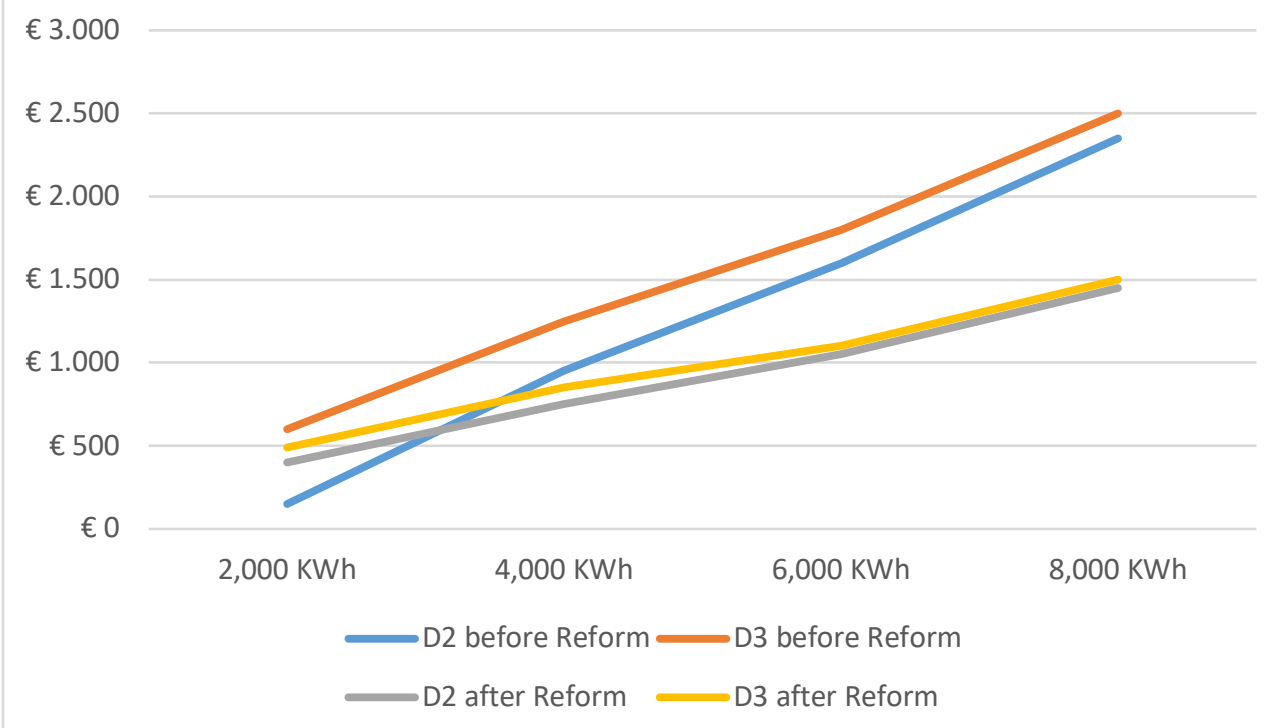


Figure 7. Comparison between electricity bills for a resident customer before and after the reform (Energy\&Strategy, 2016a)

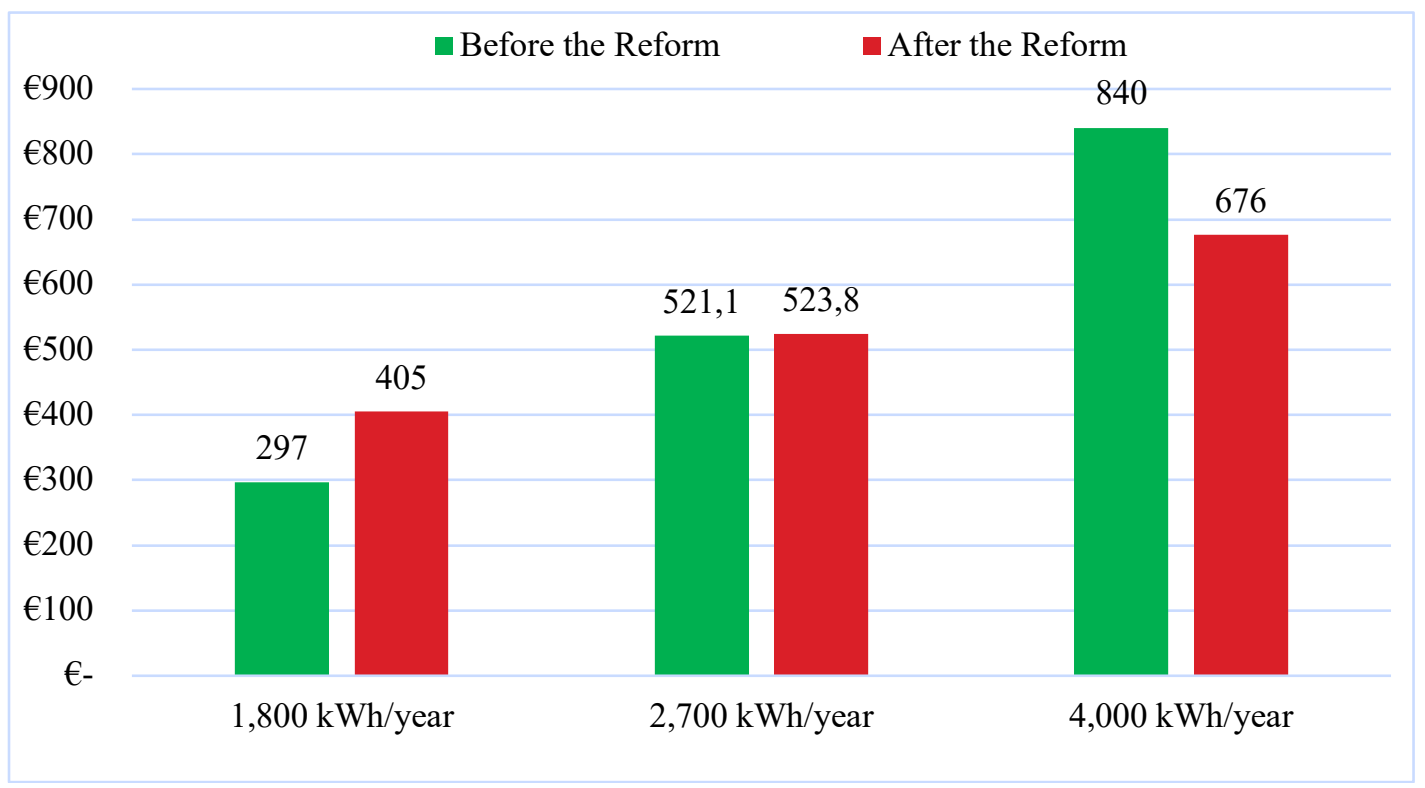

Figure 8. Comparison between electric bill for a non-resident customer before and after the reform (Energy\&Strategy, 2016a)

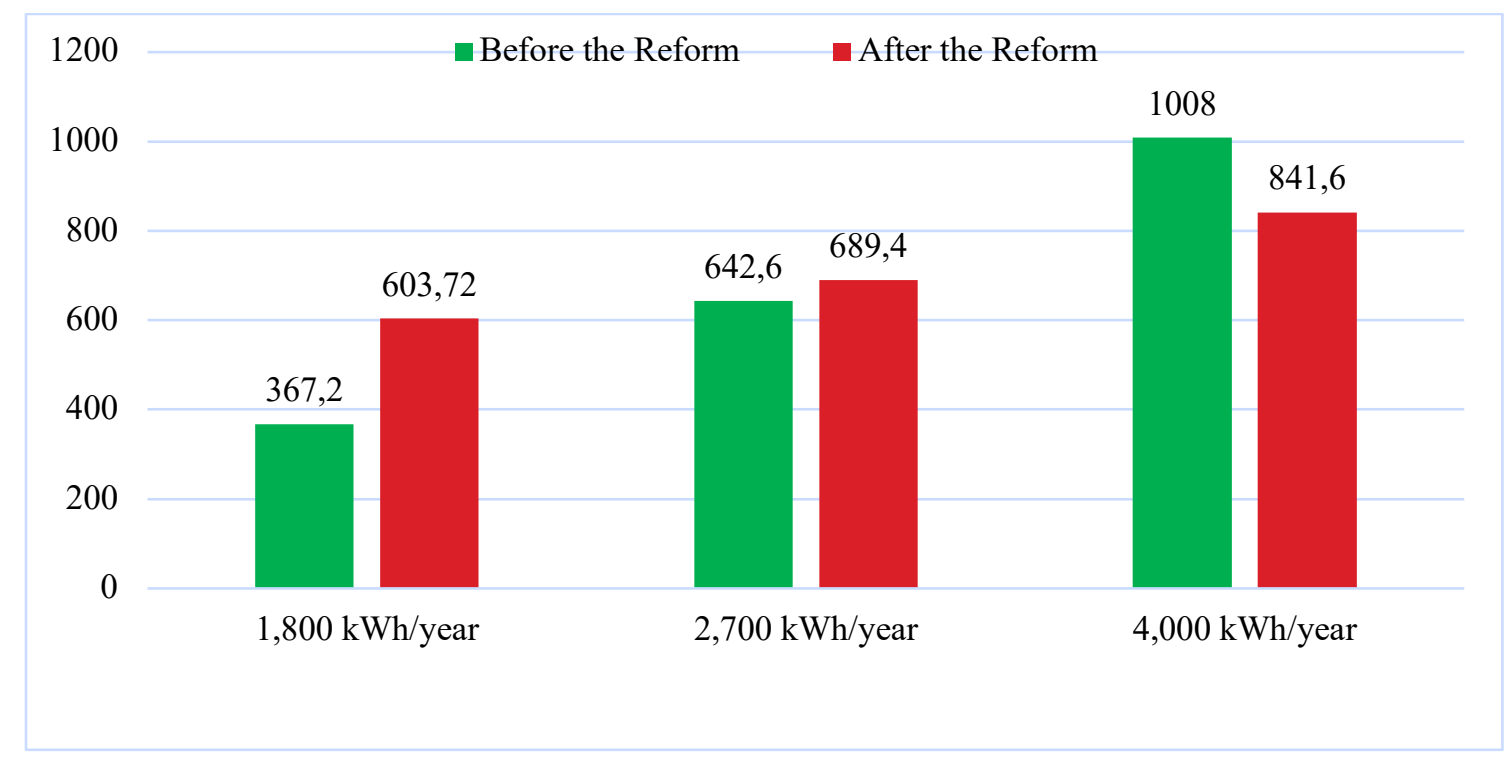


Table 1. New RES installation in Italy in MW and $€$ divided by production source for 2010-2015 (Energy\&Strategy, 2016a)

\begin{tabular}{|c|c|c|c|c|c|c|c|c|}
\hline \multicolumn{2}{|c|}{ RES } & $\mathbf{2 0 1 0}$ & $\mathbf{2 0 1 1}$ & $\mathbf{2 0 1 2}$ & $\mathbf{2 0 1 3}$ & $\mathbf{2 0 1 4}$ & $\mathbf{2 0 1 5}$ & $\begin{array}{c}\text { Cumulative } \\
\mathbf{2 0 1 0 - 2 0 1 5}\end{array}$ \\
\hline \multirow{2}{*}{ Wind } & MW & 1,100 & 900 & 1,350 & 400 & 107 & 420 & 4,277 \\
\cline { 2 - 9 } & Mln $€$ & 1,850 & 1,800 & 2,000 & 700 & 151 & 670 & 7,171 \\
\hline \multirow{2}{*}{ PV } & MW & 2,323 & 9,370 & 3,328 & 1,736 & 385 & 290 & 17,432 \\
\cline { 2 - 9 } & Mln $€$ & 7,600 & 20,135 & 6,215 & 2,508 & 658 & 558 & 37,516 \\
\hline \multirow{2}{*}{$\begin{array}{c}\text { Hydroelectric } \\
\text { power }\end{array}$} & MW & 155 & 216 & 140 & 69 & 73 & 110 & 763 \\
\cline { 2 - 9 } & Mln $€$ & 621 & 850 & 580 & 309 & 327 & 510 & 3,197 \\
\hline \multirow{2}{*}{\begin{tabular}{c} 
Bioenergies \\
\cline { 2 - 9 }
\end{tabular}} & MW & 140 & 362 & 574 & 90 & 80 & 70 & 1,316 \\
\hline \multirow{2}{*}{ Total } & MW & 517 & 1,295 & 2,070 & 388 & 347 & 308 & 4,925 \\
\cline { 2 - 9 } & Mln $€$ & 10,588 & 24,080 & 10,865 & 3,905 & 1,483 & 2,046 & 52,967 \\
\hline
\end{tabular}

Table 2. $\Delta$ price of $\mathrm{kWh}$ (referring only to the network services and system charges tariffs) segmented by consumption bands (Energy\&Strategy, 2016b)

\begin{tabular}{|c|c|c|c|}
\hline $\begin{array}{c}\text { Consumption Bands } \\
(\mathbf{k W h})\end{array}$ & $\begin{array}{c}\text { Price per } \mathbf{k W h} \\
\text { before the reform }\end{array}$ & $\begin{array}{c}\text { Price per kWh } \\
\text { after the reform }\end{array}$ & $\Delta$ 2015- 2016 \\
\hline $0-1,880$ & 0.00539 & 0.00517 & -0.00022 \\
\hline $1,801-2,640$ & 0.04236 & 0.03067 & -0.01169 \\
\hline $2,641-4,400$ & 0.08218 & 0.06709 & -0.01509 \\
\hline$>4,400$ & 0.12485 & 0.06709 & -0.05776 \\
\hline
\end{tabular}

Table 3. Electricity price for a resident and non-resident customer

\begin{tabular}{|c|c|c|c|c|c|c|}
\hline \multirow[b]{2}{*}{$\begin{array}{c}\text { Customer } \\
\text { type }\end{array}$} & \multirow[b]{2}{*}{$\begin{array}{c}\text { Annual energy } \\
\text { consumption } \\
\text { [kWh/year] }\end{array}$} & \multirow[b]{2}{*}{$\begin{array}{c}\text { Rate power } \\
{[\mathbf{k W ]}}\end{array}$} & \multicolumn{2}{|c|}{ Resident customer } & \multicolumn{2}{|c|}{ Non-resident customer } \\
\hline & & & $\begin{array}{l}\text { Energy price } \\
\text { for the end } \\
\text { costumer } \\
\text { before the } \\
\text { reform } \\
\text { [c€/kWh] }\end{array}$ & $\begin{array}{l}\text { Energy price } \\
\text { for the end } \\
\text { costumer } \\
\text { after the } \\
\text { reform } \\
\text { [c€/kWh] }\end{array}$ & $\begin{array}{l}\text { Energy } \\
\text { price for } \\
\text { the end } \\
\text { costumer } \\
\text { before the } \\
\text { reform } \\
\text { [c€/kWh] }\end{array}$ & $\begin{array}{l}\text { Energy } \\
\text { price for } \\
\text { the end } \\
\text { costumer } \\
\text { after the } \\
\text { reform } \\
\text { [c€/kWh] }\end{array}$ \\
\hline Customer \#1 & 1,800 & 3 & 16.5 & 22.5 & 20 & 33 \\
\hline Customer \#2 & 2,700 & 3 & 19.3 & 19.4 & 23.8 & 25.5 \\
\hline Customer \#3 & 4,000 & 3 & 21 & 17 & 25.2 & 21 \\
\hline
\end{tabular}

Table 4. Investment characteristics of the rooftop PV system

\begin{tabular}{|c|c|}
\hline Characteristics & Value \\
\hline Installed capacity [kW] & 3 \\
\hline CapEx [€/kW] & 2,200 \\
\hline Operating hours [h] & 1,200 \\
\hline Natural self-consumption rate [\%] & 30 \\
\hline Administrative costs [€] & 250 \\
\hline
\end{tabular}




\begin{tabular}{|c|c|}
\hline Tax deduction [\%] & 50 (of the Capex) \\
\hline Net metering ('Scambio sul posto') & Yes \\
\hline Decrease of PV performance [\%/year] & 1 \\
\hline Yearly electricity consumption [kWh] & $1,800-2,700-4,000$ \\
\hline Discount rate [\%] & 4 \\
\hline Expected life of PV system [years] & 20 \\
\hline
\end{tabular}

Table 5. Financial indicators related to the adoption a PV system by a customer with a yearly consumption of $1,800 \mathrm{kWh}$

\begin{tabular}{|l|c|c|c|c|}
\hline \multirow{2}{*}{$\begin{array}{l}\text { Financial } \\
\text { indicator }\end{array}$} & \multicolumn{2}{|c|}{ Before the reform } & \multicolumn{2}{c|}{ After the reform } \\
\cline { 2 - 5 } & Resident & Non-resident & Resident & Non-resident \\
\hline NPV [€] & 2,254 & 2,530 & 1,543 & 1,748 \\
\hline IRR [\%] & 6.9 & 8 & 6.1 & 6.2 \\
\hline PBT [years] & 14 & 12 & 16 & 15 \\
\hline
\end{tabular}

Table 6. Financial indicators related to the adoption a PV system by a customer with a yearly consumption of $2,700 \mathrm{kWh}$

\begin{tabular}{|c|c|c|c|c|}
\hline \multirow{2}{*}{$\begin{array}{c}\text { Financial } \\
\text { indicator }\end{array}$} & \multicolumn{2}{|c|}{ Before the reform } & \multicolumn{2}{c|}{ After the reform } \\
\cline { 2 - 5 } & Resident & Non-resident & Resident & Non-resident \\
\hline NPV [ $€]$ & 3,713 & 4,580 & 1,433 & 3,058 \\
\hline IRR [\%] & 7.9 & 11 & 5.8 & 7.1 \\
\hline PBT [years] & 10 & 10 & 16 & 12 \\
\hline
\end{tabular}

Table 7. Financial indicators related to the adoption a PV system by a customer with a yearly consumption of $4,000 \mathrm{kWh}$

\begin{tabular}{|c|c|c|c|c|}
\hline \multirow{2}{*}{$\begin{array}{l}\text { Financial } \\
\text { indicator }\end{array}$} & \multicolumn{2}{|c|}{ Before the reform } & \multicolumn{2}{c|}{ After the reform } \\
\cline { 2 - 5 } & Resident & Non-resident & Resident & Non-resident \\
\hline NPV [€] & 5,553 & 6,920 & 1,652 & 3,524 \\
\hline IRR [\%] & 8.6 & 13 & 6.2 & 8.3 \\
\hline PBT [years] & 9 & 8 & 16 & 11 \\
\hline
\end{tabular}

Table 8. Investment characteristics related to the adoption of new home appliances (i.e., fridge, washing machine and dishwasher) in energy efficiency Class A++

\begin{tabular}{|c|c|c|c|}
\hline Characteristic & \multicolumn{3}{|c|}{ Value } \\
\hline $\begin{array}{l}\text { Capex [€] (purchase of dishwasher, fridge } \\
\text { and washing machine }\end{array}$ & \multicolumn{3}{|c|}{1,800} \\
\hline Tax deduction $[\%]$ & \multicolumn{3}{|c|}{50 (of the Capex) over ten years } \\
\hline Yearly consumption bands [kWh/year] & 1,800 & 2,700 & 4,000 \\
\hline $\begin{array}{c}\text { Consumption rate of home appliances on } \\
\text { overall yearly consumption [\%] }\end{array}$ & \multicolumn{3}{|c|}{70} \\
\hline $\begin{array}{c}\text { Yearly energy saving related to the } \\
\text { adoption of new home appliances [kWh/year] }\end{array}$ & 378 & 567 & 840 \\
\hline $\begin{array}{l}\text { Yearly energy savings before the reform } \\
\text { for a resident customer [€/year] }\end{array}$ & 62.37 & 109.43 & 176.4 \\
\hline $\begin{array}{l}\text { Yearly energy savings before the reform } \\
\text { for a non-resident customer [€/year] }\end{array}$ & 75.6 & 134.9 & 211.68 \\
\hline $\begin{array}{l}\text { Yearly energy savings after the reform for } \\
\text { a resident customer [€/year] }\end{array}$ & 85 & 110 & 142.8 \\
\hline
\end{tabular}


Yearly energy savings after the reform for a non-resident customer [€/year]

Table 9: Financial indicators related to the adoption of new home appliances in energy efficiency Class A++

\begin{tabular}{|c|c|c|c|c|c|c|c|}
\hline \multirow{2}{*}{\multicolumn{2}{|c|}{$\begin{array}{c}\text { Financial indicator } \\
\text { Yearly consumption bands }[\mathrm{kWh} / \text { year }]\end{array}$}} & \multicolumn{3}{|c|}{ Before the Reform } & \multicolumn{3}{|c|}{ After the Reform } \\
\hline & & 1,800 & 2,700 & 4,000 & 1,800 & 2,700 & 4,000 \\
\hline \multirow{3}{*}{$\begin{array}{l}\text { Resident } \\
\text { customer }\end{array}$} & NPV $[€]$ & -160 & 505 & 1,452 & 160.5 & 513 & 977 \\
\hline & IRR [\%] & 2.5 & 8.1 & 14.9 & 5.4 & 8.2 & 11.6 \\
\hline & PBT [years] & $>20$ & 8 & 6 & 9 & 7 & 6 \\
\hline \multirow{3}{*}{$\begin{array}{l}\text { Non-resident } \\
\text { customer }\end{array}$} & NPV $[€]$ & 27.7 & 867 & 1,951 & 721.6 & 961 & 1,452 \\
\hline & IRR [\%] & 4.2 & 10.8 & 18.2 & 9.7 & 11.5 & 14.9 \\
\hline & PBT [years] & 10 & 7 & 4 & 7 & 6 & 5 \\
\hline
\end{tabular}

Table 10. Investment characteristics of two different heat pumps

\begin{tabular}{|c|c|c|}
\hline Characteristic & Old heat pump & New heat pump \\
\hline Rate Power $[\mathrm{kW}]$ & \multicolumn{2}{|r|}{16} \\
\hline Coefficient of Performance & 3 & 4.9 \\
\hline Capex $[€]$ & - & 7,000 \\
\hline Tax deduction [\%] & & 50 (of the Capex) over ten years \\
\hline Yearly consumption $[\mathrm{kWh}]$ & 7,467 & 4,571 \\
\hline $\begin{array}{l}\text { Electricity price before the reform for a } \\
\text { resident customer [c } € / \mathrm{kWh} \text { ] }\end{array}$ & \multicolumn{2}{|c|}{21} \\
\hline $\begin{array}{l}\text { Electricity price after the reform for a } \\
\text { resident customer [c } € / \mathrm{kWh} \text { ] }\end{array}$ & \multicolumn{2}{|c|}{17} \\
\hline $\begin{array}{l}\text { Electricity price before the reform for a non- } \\
\text { resident customer [c } € / \mathrm{kWh}]\end{array}$ & \multicolumn{2}{|c|}{25.2} \\
\hline $\begin{array}{l}\text { Electricity price after the reform for a non- } \\
\text { resident customer [c } € / \mathrm{kWh}]\end{array}$ & \multicolumn{2}{|c|}{21} \\
\hline $\begin{array}{l}\text { Yearly Electric bill before the reform, for a } \\
\text { resident customer [€/year] }\end{array}$ & 1,568 & 960 \\
\hline $\begin{array}{l}\text { Yearly electricity bill after the reform for a } \\
\text { resident customer [ } € / \text { year] }\end{array}$ & $1,269.4$ & 777 \\
\hline $\begin{array}{l}\text { Yearly electricity bill before the reform for a } \\
\text { non-resident customer [ } € / \text { year] }\end{array}$ & $1,881.68$ & $1,151.9$ \\
\hline $\begin{array}{l}\text { Yearly electricity bill after the reform for a } \\
\text { non-resident customer [€/year] }\end{array}$ & 1,568 & 960 \\
\hline
\end{tabular}

Table 11. Financial indicator related to an investment in a new heat pump

\begin{tabular}{|c|c|c|c|}
\hline \multicolumn{2}{|c|}{ Financial indicator } & Before the reform & After the reform \\
\hline \multirow{2}{*}{$\begin{array}{c}\text { Resident } \\
\text { customer }\end{array}$} & NPV [€] & 4,545 & 2,911 \\
\cline { 2 - 4 } & IRR [\%] & 12.9 & 9.9 \\
\cline { 2 - 4 } & PBT [years] & 6 & 7 \\
\hline \multirow{2}{*}{$\begin{array}{c}\text { Non-resident } \\
\text { customer }\end{array}$} & NPV [€] & 6,267 & $4,545.8$ \\
\cline { 2 - 4 } & IRR [\%] & 15.93 & 12.9 \\
\cline { 2 - 4 } & PBT [years] & 7 & 8 \\
\hline
\end{tabular}

